\title{
Effect of Different Transplanting Schedules on Growth, Yields and Economic Parameters of Non-Scented Rice Cultivars of Different Duration
}

\author{
Anil Kapoor ${ }^{1}$, Ishwar Singh ${ }^{2}$, Asha Serawat ${ }^{3}$, Minakshi Serawat ${ }^{1}$ \\ and Mohmmed Mohsin ${ }^{4}$
}

\author{
${ }^{1}$ GB Pant University of Agriculture and Technology, Pantnagar, Uttarakhand, India-263145 \\ ${ }^{2}$ CCS Haryana Agricultural University, Hisar, Haryana, India-125004 \\ ${ }^{3}$ Swami Keshwanand Rajasthan Agriculture University, Bikaner, Rajasthan, India-334006 \\ ${ }^{4}$ Maharana Pratap University of Agriculture \& Technology, \\ Udaipur, Rajasthan-313001, India \\ *Corresponding author
}

\section{A B S T R A C T}

\begin{tabular}{|c|}
\hline Keywords \\
\hline $\begin{array}{l}\text { Transplanting, } \\
\text { Non-scented } \\
\text { variety, Rice, } \\
\text { Growth, } \\
\text { Yield, Economics }\end{array}$ \\
\hline Article Info \\
\hline $\begin{array}{l}\text { Accepted: } \\
26 \text { January } 2021 \\
\text { Available Online: } \\
10 \text { February } 2021\end{array}$ \\
\hline
\end{tabular}

A field experiment was conducted during kharif 2015 at Rice Research Station, Kaul (Kaithal) of CCS Haryana Agricultural University, Hisar to study the effect of different dates of transplanting on growth, yields and economics of non-scented rice varieties. The experiment conducted in split plot design comprised three dates of transplanting viz. June 15 , July 05 , and July 25 in main plots and four non scented rice varieties viz. HKR-48, HKR-47, HKR-127 and HKR-128 in sub plots with four replications. Early transplanted crop (June 15 and July 5) showed sign of good growth having taller plants, high crop dry matter accumulation, leaf area, leaf area index, crop growth rate and relative growth rate than delayed transplanted crop (July 25). Among the different varieties growth attributes were significantly higher in medium duration varieties HKR-128 followed by HKR-127 as compared to that in mid-early HKR-47 and early duration variety HKR-48. The medium duration variety HKR-128 recorded significantly higher yield $(69.67 \mathrm{q} / \mathrm{ha})$ than HKR-127 (66.04 q/ha), HKR-47 (63.82 q/ha) and HKR-48 (52.65 q/ha). The transplanting June 15 was found beneficial with maximum net return (Rs. 24020/ha) and B:C (1.27) followed by July 05 (Rs. 22305/ha and 1.25, respectively) and July 25 (Rs. -10403/ha and 0.88, respectively). The HKR-128 gave the highest net return (Rs. 22640/ha) and B:C (1.25) as compared to other varieties.

\section{Introduction}

Apart from different inputs for yield variability the Time is the key factor which decides that how the crops behave or responded to different inputs. It not only affects the growth and yield of crops, actually it decides the growth and yield for a crop. In rice cultivation, scheduling of times of transplanting play a vital role because different variety shows different photo sensitiveness, thermo sensitivity and 
vegetative lag period for a different duration of climate. Neither too early nor too late transplanting is good for rice cultivation; it results in drastic reduction in terms of growth and yield. The selection of suitable variety for existing climatic condition is also an important input. A short duration variety may perform better from early planting than that of late planting because of the fact that those varieties complete their life cycle with in short period having less effect of photoperiod and temperature. Like that photo and thermo insensitive varieties may perform better under normal to late planting condition with limited effect on yield of crop. So, to obtain an excellent amount of yield it is necessary to choose an appropriate time for transplanting according to available varieties and seasonal climate. The present field investigations were, therefore, conducted to find out the effect of transplanting dates on different duration nonscented varieties of rice.

\section{Materials and Methods}

A field experiment was conducted during rainy Kharif season 2015 at Rice Research Station, Kaul (Kaithal) of CCS Haryana Agricultural University, Hisar, Haryana on a clay loam texture soil which alkaline in reaction having $\mathrm{pH} 8.1$, low in organic carbon $0.32 \%$, electrical conductivity $0.27 \mathrm{dS} / \mathrm{m}$, low in available nitrogen (161.2 kg N/ha), medium in phosphorus (16.2 kg P/ha) and high in available potassium $(328.2 \mathrm{~kg} \mathrm{~K} / \mathrm{ha})$. The four non-scented varieties viz. HKR-48 (early duration), HKR-47 (mid-early duration), HKR-127 (medium duration) and HKR-128 (medium duration) were tested at three different dates of transplanting viz. June 15, July 05 and July 25. The split plot design used to carry out the experiment, keeping transplanting dates in main plots and varieties in sub-plots with four replications. The thirty days old seedlings were transplanted at spacing of $20 \times 15 \mathrm{~cm}$. recommended dose of
Fertilizer was applied with Zinc through zinc sulphate @ $25 \mathrm{~kg}$ ZnSO4/ha as basal application before transplanting. Plant protection measures were adopted as per the recommendation. The crop was harvested at maturity and threshed as per schedule. The data for growth attributes; Plant height $(\mathrm{cm})$, Dry matter accumulation $\left(\mathrm{g} / \mathrm{m}^{2}\right)$, Leaf area $\left(\mathrm{cm}^{2}\right)$ were recorded at different stage of growth at 30, 60, 90 Days after transplanting and at harvest. From available different interval different growth rates; Crop growth rate $\left(\mathrm{g} / \mathrm{m}^{2} /\right.$ day $)$, Relative growth rate $(\mathrm{g} / \mathrm{g} /$ day $)$ were calculated. The grain yield is calculated from different yield attributes data viz. number of panicles/m2, grains/panicle, 1000 -grains weight at harvest.

\section{Results and Discussion}

\section{Growth studies}

Early transplanted crop (June 15 and July 5) showed greater plant height, crop dry matter accumulation, leaf area, leaf area index, crop growth rate and relative growth rate than delayed transplanted crop (July 25). This might be due to longer vegetative period of the crop under early transplanting, due to which the plants accumulated more photosynthates which were utilized for growth of vegetative organs of the plant. Jand et al., (1994) and Bali and Uppal (1995) observed higher dry matter accumulation under early planting of rice.

Plant height of rice crop increased very rapidly up to 60 DAT and then the rate of increase was marginal from 60 to 90 DAT and lowest from 90 DAT to harvest (Table 1). Paliwal et al., (1996) also reported that late planting reduced plant height of rice cultivars. Among the different non scented varieties HKR-128 recorded significantly taller plants which were at par to that recorded in variety HKR-127. 
Table.1 Effect of different dates of transplanting on plant height

\begin{tabular}{|l|c|c|c|c|}
\hline \multicolumn{1}{|c|}{ Treatments } & \multicolumn{4}{c|}{ Plant height (cm) } \\
\cline { 2 - 5 } & 30 DAT & 60 DAT & 90 DAT & Harvest \\
\hline \multicolumn{1}{|c|}{ Main plots (transplanting dates) } & & & & \\
\hline D1: June 15 & 56.91 & 97.72 & 119.31 & 120.28 \\
\hline D2: July 05 & 55.75 & 96.85 & 118.41 & 119.56 \\
\hline D3: July 25 & 54.30 & 86.94 & 101.62 & 105.44 \\
\hline SEm \pm & 0.36 & 0.37 & 0.91 & 1.15 \\
\hline CD at 5\% level & 1.26 & 1.32 & 3.22 & 4.06 \\
\hline Sub plots (varieties) & & & & \\
\hline V1: HKR-48 & 53.48 & 90.36 & 104.29 & 105.19 \\
\hline V2: HKR -47 & 54.79 & 93.11 & 114.33 & 114.60 \\
\hline V3: HKR- 127 & 57.05 & 94.42 & 115.63 & 117.10 \\
\hline V4: HKR-128 & 58.28 & 96.47 & 117.21 & 119.48 \\
\hline SEm \pm & 0.43 & 0.62 & 0.94 & 1.04 \\
\hline CD at 5\% level & 1.26 & 1.81 & 2.75 & 3.04 \\
\hline
\end{tabular}

Table.2 Effect of different dates of transplanting on plant dry matter accumulation

\begin{tabular}{|l|c|c|c|c|}
\hline \multirow{2}{*}{ Treatments } & \multicolumn{4}{c|}{ Dry matter accumulation $\left(\mathbf{g} / \mathbf{m}^{2}\right)$} \\
\cline { 2 - 5 } & 30 DAT & 60 DAT & 90 DAT & Harvest \\
\hline \multicolumn{1}{|c|}{ Main plots (transplanting dates) } & & & & \\
\hline D1: June 15 & 62.55 & 842.60 & 1275.55 & 1384.89 \\
\hline D2: July 05 & 61.56 & 823.15 & 1229.46 & 1320.23 \\
\hline D3: July 25 & 59.43 & 717.92 & 1062.46 & 1116.30 \\
\hline SEm \pm & 0.42 & 3.28 & 3.75 & 1.48 \\
\hline CD at 5\% level & 1.47 & 11.58 & 13.22 & 5.23 \\
\hline \multicolumn{1}{|c|}{ Sub plots (varieties) } & & & & \\
\hline V1: HKR-48 & 55.89 & 711.68 & 1070.29 & 1117.06 \\
\hline V2: HKR -47 & 60.83 & 782.15 & 1170.34 & 1258.37 \\
\hline V3: HKR- 127 & 63.64 & 831.80 & 1242.47 & 1340.17 \\
\hline V4: HKR-128 & 64.37 & 852.59 & 1273.54 & 1379.61 \\
\hline SEm \pm & 0.51 & 7.28 & 8.04 & 7.96 \\
\hline CD at 5\% level & 1.50 & 21.23 & 23.44 & 23.23 \\
\hline
\end{tabular}


Table.3 Effect of different dates of transplanting on leaf area

\begin{tabular}{|l|c|c|c|}
\hline \multirow{2}{*}{\multicolumn{1}{|c|}{ Treatments }} & \multicolumn{3}{c|}{ Leaf area $\left(\mathbf{c m}^{2}\right)$} \\
\cline { 2 - 4 } & 30 DAT & 60 DAT & 90 DAT \\
\hline Main plots (transplanting dates) & & & \\
\hline D1: June 15 & 462.34 & 1609.18 & 1262.96 \\
\hline D2: July 05 & 458.74 & 1575.72 & 1252.16 \\
\hline D3: July 25 & 408.78 & 1323.69 & 1133.80 \\
\hline SEm \pm & 1.47 & 14.58 & 5.83 \\
\hline CD at 5\% level & 5.18 & 51.43 & 20.56 \\
\hline Sub plots (varieties) & & & \\
\hline V1: HKR-48 & 403.31 & 1390.68 & 1142.62 \\
\hline V2: HKR -47 & 443.28 & 1495.71 & 1194.98 \\
\hline V3: HKR- 127 & 459.73 & 1564.30 & 1259.13 \\
\hline V4: HKR-128 & 466.87 & 1590.76 & 1268.49 \\
\hline SEm \pm & 5.65 & 12.78 & 7.75 \\
\hline CD at 5\% level & 16.47 & 37.28 & 22.59 \\
\hline
\end{tabular}

Table.4 Effect of different dates of transplanting on leaf area index

\begin{tabular}{|c|c|c|c|}
\hline \multirow{2}{*}{ Treatments } & \multicolumn{3}{|c|}{ Leaf area index (LAI) } \\
\cline { 2 - 4 } Main plots (transplanting dates) & 30 DAT & 60 DAT & 90 DAT \\
\hline D1: June 15 & & & \\
\hline D2: July 05 & 1.53 & 5.31 & 4.17 \\
\hline D3: July 25 & 1.51 & 5.20 & 4.13 \\
\hline SEm \pm & 1.35 & 4.37 & 3.74 \\
\hline CD at 5\% level & 0.01 & 0.05 & 0.02 \\
\hline Sub plots (varieties) & 0.02 & 0.17 & 0.07 \\
\hline V1: HKR-48 & & & \\
\hline V2: HKR -47 & 1.33 & 4.59 & 3.77 \\
\hline V3: HKR- 127 & 1.46 & 4.94 & 3.94 \\
\hline V4: HKR-128 & 1.52 & 5.16 & 4.16 \\
\hline SEm \pm & 1.54 & 5.25 & 4.19 \\
\hline CD at 5\% level & 0.02 & 0.04 & 0.03 \\
\hline & 0.05 & 0.12 & 0.08 \\
\hline
\end{tabular}


Table.5 Effect of different dates of transplanting on crop growth rate

\begin{tabular}{|c|c|c|c|c|}
\hline \multirow{2}{*}{ Treatments } & \multicolumn{4}{|c|}{ Crop growth rate $\left(\mathbf{g} / \mathbf{m}^{2} / \mathbf{d a y}\right)$} \\
\cline { 2 - 5 } & $\mathbf{0 - 3 0}$ DAT & $\begin{array}{c}\mathbf{3 1 - 6 0} \\
\text { DAT }\end{array}$ & $\begin{array}{c}\mathbf{6 1 - 9 0} \\
\text { DAT }\end{array}$ & $\begin{array}{c}\text { At } \\
\text { Harvest }\end{array}$ \\
\hline Main plots (transplanting dates) & & & & \\
\hline D1: June 15 & 2.09 & 26.00 & 14.43 & 3.28 \\
\hline D2: July 05 & 2.05 & 25.39 & 13.55 & 2.33 \\
\hline D3: July 25 & 1.98 & 21.95 & 11.48 & 1.97 \\
\hline SEm \pm & 0.02 & 0.12 & 0.15 & 0.11 \\
\hline CD at 5\% level & 0.05 & 0.42 & 0.53 & 0.37 \\
\hline Sub plots (varieties) & & & & \\
\hline V1: HKR-48 & 1.87 & 21.86 & 11.95 & 2.12 \\
\hline V2: HKR -47 & 2.03 & 24.04 & 12.94 & 2.44 \\
\hline V3: HKR- 127 & 2.12 & 25.60 & 13.69 & 2.68 \\
\hline V4: HKR-128 & 2.15 & 26.28 & 14.03 & 2.86 \\
\hline SEm \pm & 0.02 & 0.24 & 0.32 & 0.17 \\
\hline CD at 5\% level & 0.05 & 0.71 & 0.94 & 0.51 \\
\hline
\end{tabular}

Table.6 Effect of different dates of transplanting on relative growth rate

\begin{tabular}{|c|c|c|c|}
\hline \multirow[b]{2}{*}{ Treatments } & \multicolumn{3}{|c|}{ Relative growth rate $(g / g /$ day $)$} \\
\hline & 31-60 DAT & 61-90 DAT & At Harvest \\
\hline \multicolumn{4}{|c|}{ Main plots (transplanting dates) } \\
\hline D1: June 15 & 86.67 & 13.86 & 2.46 \\
\hline D2: July 05 & 86.43 & 13.38 & 1.82 \\
\hline D3: July 25 & 82.98 & 13.05 & 1.59 \\
\hline SEm \pm & 0.34 & 0.19 & 0.09 \\
\hline $\mathrm{CD}$ at $5 \%$ level & 1.20 & NS & 0.30 \\
\hline \multicolumn{4}{|l|}{ Sub plots (varieties) } \\
\hline V1: HKR-48 & 84.69 & 13.14 & 1.57 \\
\hline V2: HKR -47 & 85.07 & 13.34 & 2.00 \\
\hline V3: HKR- 127 & 85.60 & 13.46 & 2.08 \\
\hline V4: HKR-128 & 86.07 & 13.79 & 2.18 \\
\hline SEm \pm & 0.42 & 0.35 & 0.10 \\
\hline $\mathrm{CD}$ at $5 \%$ level & NS & NS & NS \\
\hline
\end{tabular}


Table.7 Effect of different dates of transplanting on yield

\begin{tabular}{|c|c|c|c|c|}
\hline Treatments & $\begin{array}{c}\text { Grain yield } \\
(\mathbf{t} / \mathbf{h a})\end{array}$ & $\begin{array}{c}\text { Straw yield } \\
(\mathbf{t} / \mathbf{h a})\end{array}$ & $\begin{array}{c}\text { Biological } \\
\text { yield (t/ha) }\end{array}$ & $\begin{array}{c}\text { Harvest } \\
\text { index (\%) }\end{array}$ \\
\hline $\begin{array}{c}\text { Main plots (transplanting } \\
\text { dates) }\end{array}$ & & & & \\
\hline D1: June 15 & 7.060 & 8.331 & 15.392 & 45.87 \\
\hline D2: July 05 & 6.949 & 8.284 & 15.233 & 45.61 \\
\hline D3: July 25 & 4.903 & 6.859 & 11.712 & 41.50 \\
\hline SEm \pm & .07573 & .19792 & .27081 & 0.60 \\
\hline CD at 5\% level & .26140 & .69820 & .95534 & 2.20 \\
\hline Sub plots (varieties) & & & & \\
\hline V1: HKR-48 & 5.265 & 6.941 & 12.206 & 43.13 \\
\hline V2: HKR -47 & 6.382 & 8.014 & 14.396 & 44.33 \\
\hline V3: HKR- 127 & 6.604 & 8.257 & 14.861 & 44.43 \\
\hline V4: HKR-128 & 6.967 & 8.587 & 15.554 & 44.79 \\
\hline SEm \pm & .08879 & 190.15 & .28426 & 0.70 \\
\hline CD at 5\% level & .25771 & .55472 & .82925 & NS \\
\hline
\end{tabular}

Table.8 Effect of different dates of transplanting on economics of rice

\begin{tabular}{|c|c|c|c|}
\hline \multirow[b]{2}{*}{ Treatments } & \multicolumn{3}{|c|}{ Economics } \\
\hline & $\begin{array}{c}\text { Gross returns } \\
\text { ( //ha) }\end{array}$ & $\begin{array}{l}\text { Net returns } \\
\text { (/ha) }\end{array}$ & $\begin{array}{l}\text { Benefit-cost } \\
\text { ratio }\end{array}$ \\
\hline \multicolumn{4}{|c|}{ Main plots (transplanting dates) } \\
\hline D1: June 15 & 113605 & 24020 & 1.27 \\
\hline D2: July 05 & 111890 & 22305 & 1.25 \\
\hline D3: July 25 & 79182 & -10403 & 0.88 \\
\hline \multicolumn{4}{|c|}{ Sub plots (varieties) } \\
\hline V1: HKR-48 & 84797 & -3923 & 0.96 \\
\hline V2: HKR -47 & 102839 & 13254 & 1.15 \\
\hline V3: HKR- 127 & 106407 & 16822 & 1.19 \\
\hline V4: HKR-128 & 112225 & 22640 & 1.25 \\
\hline
\end{tabular}


The variety HKR-48 produced significantly shortest plants compared to all other varieties. These finding are in agreement with that of Dhiman et al., (1995). Among the different varieties plant height, , dry matter accumulation (Table 2), leaf area (Table 3), leaf area index (Table 4), crop growth rate (Table 5) and relative growth rate (Table 6) were significantly higher in medium duration varieties HKR-128 followed by HKR-127 as compared to that in mid-early HKR-47 and early duration variety HKR-48. This may be due to high yielding vigour shown by the HKR-128 followed by HKR-127. On other hand shorter duration variety HKR-48 could not match the growth of mid-early and medium duration high yielding varieties due to comparatively less time for production and translocation of photosynthates. These finding are in agreement with that of Chaturvedi et al., (2004) who reported that longer the crop duration higher was the dry matter production and growth. Samdhia (1996) found that LAI declined gradually as the planting was delayed beyond July15. Singh et al., (1996b) reported that total tillers per plant of the crop transplanted on May 16 and May 31 was significantly more than that of the crop transplanted on June 16.

\section{Yield}

The yield attributing characters are in fact a reflection of vegetative growth of a plant. The yield (grain \& straw) were recorded highest in earlier transplanted crop (June 15 and July 05). The yield attributes of the crop transplanted on June 15 and July 05 were statistically similar but significantly superior to the crop transplanted on July 25 (Table 7). The highest yield under early transplanting may be attributed to cumulative effect of greater plant height, more dry matter accumulation, and yield attributes like more panicles $/ \mathrm{m}^{2}$ and grains/panicle. These findings are in general agreement with those reported by Ashraf et al., (1989), Singh et al., (1992), Bali and Uppal (1995), Chopra and Chopra (2004), Ram et al., (2005) and Chopra et al., (2006). The lower yield under late transplanted crop may also be attributed to comparatively low temperature in the late planted crop. These findings are in general agreement with those reported by Bali et al., (1993).

Among the varieties, medium duration varieties (HKR-128 and HKR-127) gave the highest grain and straw yields (Table 7) and proved significantly better than mid-early and early duration varieties. This was obviously due to more tillering, higher dry matter accumulation, more panicles $/ \mathrm{m}^{2}$ and grains/panicle in these varieties as compared to other varieties. The mid-early duration variety (HKR-47) was significantly superior in terms of grains and straw yields to early duration variety (HKR-48) because of greater number of panicles $/ \mathrm{m}^{2}$ and grains/panicle as well as higher dry matter accumulation as compared to HKR-48. Joon et al., (1989), Ram et al., (2005) and Singh et al., (2005) also reported the superiority of medium duration varieties over short duration ones. The lowest yield in short duration varieties might be due to less time available to reproductive phase, distribution of photosynthates, which might have resulted in less number of panicle $/ \mathrm{m}^{2}$, grains/panicle and 1000-grains weight.

\section{Economics}

The early transplanted crop (June 15 and July 05) gave higher gross return, net return and benefit cost ratio as compared to the crop transplanted on July 05 and July 25 (Table 8). This might be due to higher grain and straw yields produced by early planted crop. Similar results were observed by Chaudhary et al., (2011). The highest gross return, net return and benefit cost ratio were recorded by HKR- 
128 as compared to other varieties under treatments which were due to higher grain and straw yield. The next economically best variety was HKR-127 followed by HKR-47 followed by HKR-48. The net return and benefit cost ratio were lowest with HKR-48, even when the cost of cultivation was less as compared to other varieties. This may be due to lower yield of HKR-48 than all other varieties.

\section{References}

Ashraf, M., Mahmood, S. and Munsif, M. (1989). Relationship of transplanting time and grain yield of basmati- 385 . Int. Rice Res. Newsl., 14(1): 8.

Bali, A.S. and Uppal, U.S. (1995). Effect of date of transplanting and water management practices on yield of basmati rice (Oryza sativa). Indian Journal of Agronomy. 40(20): 186-192.

Bali, A.S., Singh, K.N. and Khan, G.M. (1993). Effect of transplanting dates on promising genotypes of rice (Oryza sativa) under Kashmir Valley conditions. Indian Journal of Agronomy. 37(4): 805-806.

Chaturvedi, S., Lal, Pyare; Singh, A.P. and Tripathi, M.K. 2004 Agronomic and morpho-physiological analysis of growth and productivity in hybrid rice (Oryza sativa L.) Annals of Biology. 20(2): 233-238.

Chaudhary S.K., Singh J.P., and Jha A. (2011). Effect of integrated nutrient management on yield, quality and nutrient uptake of rice (Oryza sativa) different dates of transplanting. Indian Journal of Agronomy 56 (3): 228-231.

Chopra, N.X., Chopra, Nisha and Yadav, R.N. (2006). Effect of transplanting dates on seed yield and quality of paddy cv. Pusa-44. Seed Res., 94(2): 288-290.

Chopra, Neelam and Chopra, Nisha (2004). Influence of transplanting dates on heat requirement of different phonological stages and subsequently yield and quality of scented rice (Oryza sativa) seed. Indian J. Agric. Sci., 74(8): 415419.

Dhiman, S.D., Om, H., Singh, B. and Bikram, Singh (1995). Yield stabilization of scented dwarf rice under late planting through spacing and seedling age. Haryana Agricultural University Journal of Research. 25 (3): 95-99.

Jand, V.J., Bains, G.S. and Movi, H.S. (1994). Effect of different transplanting dates on biomass production and its partitioning in various plant parts of rice crop. Indian J. Ecol., 21(1): 13-18.

Joon, R.K., Singh, O.P., Om, H. and Panwar, D.V.S. 1989. Performance of modem rice varieties under different time of transplanting in Haryana. Agriculture Science Digest. 9: 225-228.

Paliwal, A.K., Kandalkar, V.S., Paraye ,P.M. and Tomar, N.S. (1996). Effect of transplanting time on grains yield and its attribute in dwarf rice. Indian $J$. Agric. Sci., 66(1): 48-50.

Ram, M., Singh, I., Om, H. and Nandal, D.P. 2005. Performance of rice (Oryza sativa L.) varieties and hybrids under varying time of transplanting in Haryana. Haryana Journal of Agronomy, 21(1): 18-20.

Samdhia, S. (1996). Relative performance of hybrids rice under different dates and densities of planting. International Rice Research Notes. 21 (2): 81-82.

Singh, C.B., Aujla, T.S., Sandhu, B.S. and Khera, K.L. (1996b). Effect of transplanting date and irrigation regime on growth, yield and water use efficiency in rice in northern India. Indian Journal of Agricultural Science. 66 (3): 137-141.

Singh, G., Singh, O.P., Singh, B.B., Singh, R.S. and Yadav, R.A. 1992. Effect of transplanting dates and densities of 
nurseries on yield and yield attributes of rainfed lowland rice. Crop Res. 5(3): 565-567.

Singh, I., Ram, M., Om, H. and Nandal, D.P.
2005. Effect of time of transplanting on performance of non-scented rice (Oryza sativa) varieties in Haryana. Haryana Journal of Agronomy. 21(2): 104-106.

\section{How to cite this article:}

Anil Kapoor, Ishwar Singh, Asha Serawat, Minakshi Serawat and Mohmmed Mohsin. 2021. Effect of Different Transplanting Schedules on Growth, Yields and Economic Parameters of Non-Scented Rice Cultivars of Different Duration. Int.J.Curr.Microbiol.App.Sci. 10(02): 33193327. doi: https://doi.org/10.20546/ijcmas.2021.1002.364 